УДК 342.951:347.79 (477)

DOI https://doi.org/10.51989/NUL.2021.4.35

\title{
УКРАЇНА - ДЕРЖАВА ПРАПОРА: КОНЦЕПТ «РЕАЛЬНИЙ ЗВ'ЯЗОК» У КОНТЕКСТІ ПРАВОВОЇ (МОРСЬКОЇ) ДОКТРИНИ (ЧАСТИНА І. СТАНОВЛЕННЯ)
}

\author{
Кузнєцов Сергій Сергійович, \\ кандидат політичних наук, \\ директор \\ Навчального центру фахівців морського транспорту
}

У статті досліджується становлення сучасних інститутів реєстрації морських суден і реального зв'язку між судном і державою його реєстрації. Підкреслюється, що Морською доктриною одним із пріоритетних національних інтересів України на морі визнано посилення позиції серед провідних морських держав шляхом створення та розвитку національних судноплавних компаній і торговельного флоту. Для поліпшення стану морської діяльності необхідно створити економічні стимули для реєстрації суден під українським прапором. Акцентовано на важливості створення обґрунтованого податкового режиму судноплавства, що відповідає податковим умовам відкритих реєстрів європейських держав і надання режиму найбільшого сприяння інвестуванню в морський і внутрішній водний транспорт України. Аналізуються визначення та зміст понять «відкрите море», «свобода відкритого моря» як такі, що мають безпосереднє відношення до реєстрації суден і здійснення над ними юрисдикції держави прапора. Досліджується історичний аспект питання про надання права на прапор і практика запровадження державами так званої «зручної реєстрації». Зазначається, що відсутність міжнародно-правового закріплення вимог, навіть мінімальних стандартів, пов'язаних із реалізацією державами права надання національності й права плавання під прапором, привело до появи полегшених, «зручних» реєстрів. Робиться висновок про те, що питання про надання права на прапор держави є фактично питанням можливості допуску іноземного капіталу до свого торговельного флоту. Автор погоджується з поясненням Комісії міжнародного права 1956 року про те, що надання національності не є простою адміністративною формальністю, яка не супроводжується жодними гарантіями того, що судно прапора дійсно зв'язано з державою прапора, тобто фактично існує зв'язок, який виявляється не лише у виданні свідоцтва про реєстрацію та розуміє поняття «реальний зв'язок» як об'єднувальне, таке, що містить у собі певні складові частини. Відзначається, що дотепер не створено загальнообов'язкових вимог щодо реєстрації суден державами прапорів.

Ключові слова: відкрите море, свобода відкритого моря, свобода судноплавства, право судноплавства, держава прапора, судно прапора, реальний зв'язок, реєстрація суден.

Kuznietsov Serhii. Ukraine - a country of a flag: "genuine link" concept in the context of legal (maritime) doctrine (Part I. Formation)

The article researches formation of the modern institutes of marine ships registration and genuine link between a ship and a country of its registration. It is emphasized that Maritime doctrine recognizes strengthening of positions among maritime states by creation and development of the national shipping companies and merchant fleet as one of the priority national interests for Ukraine on the sea. To improve maritime activity, it is necessary to create economic incentives for ships registration under Ukrainian flag. The importance of justified shipping tax regime formation, which meets tax conditions of the open registers of the European states and boosting the regime with investments in sea and inland water transport of Ukraine are outlined as well. The article analyses definition and meaning of notions "high sea", "freedom of the high seas" as such that have direct relation to ships registration and execution of the flag state jurisdiction over them. A historical aspect of question about granting the right to the flag and implementation practice of so called "convenient registration" is studied. It is indicated that lack of international legal requirements consolidation, even minimal standards related to state execution of the right to grand nationality and right to sail under the flag, has led to formation of simplified "convenient" registers. It is concluded that the question about granting the right 
to the state flag is actually a question about a possibility of a foreign capital admittance to its merchant fleet. The author agrees with the Committee of the International Law 1956 explanation that granting a nationality is not a simple administrative formality, which is not backed up by any guarantees that the ship of the flag is actually connected to the state of the flag, that is, there is a connection that in manifested not only in the issuance of the registration certificate but understands the notion of "genuine link" as unifying, such that contains certain components. It is marked that as of today there is no mandatory requirements for ships registration by the states of the flag.

Key words: high seas, freedom of the high seas, freedom of navigation, law of navigation, flag state, flag ship, genuine link, ship registration.

28 грудня 2018 року набула чинності Постанова Кабінету Міністрів України від 18 грудня 2018 року № 1108 «Про внесення змін до Морської доктрини України на період до 2035 року» [1]. Цією постановою було затверджено другу - чинну на цей час (01 липня 2021 року) - редакцію Морської доктрини України на період до 2035 року (далі - Мордок 2018). Правовою підставою формування та затвердження Мордок 2018 став Указ Президента України від 12 жовтня 2018 року № 320/2018 [2], яким було введено в дію рішення Ради Національної безпеки і оборони України (далі - РНБО) від 12 жовтня 2018 року «Про невідкладні заходи щодо захисту національних інтересів на Півдні й Сході України, і Чорному й Азовському морях і Керченській протоці». У цьому рішенні РНБО, розглянувши загрози національній безпеці, «констатувала наявність умов, що можуть привести до критичної дестабілізації економічній і суспільно-політичній ситуації» [3]. Звідси, оскільки Морська доктрина України «визначає стратегію та основні напрями подальшого розвитку» України як морської держави, «виникла потреба» в її «оновленні» (Мордок 2018 «Загальні питання»). Але в умовах «суттєвого зменшення» кількості суден під українськім прапором, слід враховувати світовий досвід, який свідчить, що «введення міжнародної реєстрації суден із спеціальним режимом оподаткування» сприяло «концентрації флоту» під національним прапором (Мордок 2018 «Сучасний стан сфери морської діяльності»). Водночас до пріоритетних національних інтересів на морі належить, серед інших, «посилення позиції України серед провідних морських держав» шляхом, зокрема, «підтримки свободи відкритого моря», створення та розвиток «національних судноплавних компаній і національного торговельного флоту»
(Мордок 2018 «Національні інтереси на морі»). Для «загального поліпшення стану» морської діяльності необхідно «створити економічні стимули» для реєстрації суден під українським прапором (Мордок 2018 «Мета, принципи й напрями реалізації морської політики»), зокрема «обґрунтованого» податкового режиму судноплавства, що відповідає податковим умовам «відкритих реєстрів європейських держав», та «надання режиму найбільшого сприяння інвестуванню» у морський і внутрішній водний транспорт. Водночас одним із напрямів «відродження та розвитку торговельного мореплавства» $\epsilon$ «боротьба із субстандартним судноплавством» (Мордок 2018 «Розвиток морської індустрії»), а одним із напрямів «просування» національних інтересів $\epsilon$ «піднесення іміджу України як морської держави, зокрема шляхом демонстрації державного прапора» (Мордок 2018 «Розвиток військово-морської діяльності»).

Вищенаведене дає підстави стверджувати, що забезпечення якості й ефективності Мордок 2018 значною мірою залежатиме від наукового обґрунтування визначення стратегії та основних напрямів розвитку України як держави прапора, що слід розглядати як наукове завдання, і слугує обґрунтуванням актуальності дослідження саме концепту «реальний зв'язок» у контексті правової (морської) доктрини для України [4, с. 279]. Отже, об'єктом дослідження визначено формування загальнотеоретичних основ правової (морської) доктрини для України, а предметом дослідження - концепт «реальний зв'язок» у контексті правової (морської) доктрини для України як держави прапора, зокрема дослідження визначення, змісту й ролі реєстрації суден як елементу забезпечення «реального зв'язку» між Україною і українськими суднами (суднами України). 
Мета дослідження - дослідити концепт «реальний зв'язок» у контексті правової (морської) доктрини для України як держави прапора, зокрема дослідження визначення, змісту і ролі реєстрації суден як елементу забезпечення «реального зв'язку» між Україною і українськими суднами (суднами України). Для досягнення мети дослідження проаналізовано наукові здобутки українських та іноземних вчених, які становлять його емпіричну базу. Це наукові праці таких вчених, як: С. Алексєєв, О. Джураєва, Ю. Оборотов, А. Рябошапченко, Г. Шершеневич - у сфері загальнотеоретичної юриспруденції; Т. Аверочкіна, Г. Анцелевич, В. Верещєтін, Є. Додін, С. Ківалов, А. Колодкін, Н. Королева, С. Кузнецов, Р. Фогель, В. Царев, О. Шемякін - у сфері морського права; дисертаційні дослідження та наукові праці Г. Єгіяна (1989 рік) і М. Никитюк (2009 рік); наукові статті практиків морського бізнесу: Ю. Булушева, Г. Іванова, О. Кифака, А. Коротаєва, Н. Мельнікова, С. Нікуліна, М. Шевченка, С. Яшина; а також наукові доробки членів Інституту міжнародного права й Комісії міжнародного права, викладені у відповідних публікаціях.

Зміни у «національній державі в епоху глобалізації, інформатизації та індивідуалізації суспільства» визначають підвищення значення «вдосконалення механізму дії права, інститутів і функцій держави», що може свідчити про «актуальність проблематики сучасної держави», яка пов'язана із цими змінами [5, с. 360, 361]. Отже, «вивчення механізму сучасної держави, специфіки його організації, функціонування та правового забезпечення» становить «один з пріоритетних напрямів загальнотеоретичних досліджень» [6, с. 358, 359]. «Нині стрімко» відбувається становлення «єдиного глобального простору» та формується «новий світовий порядок», що викликає необхідність у вироблені особливих механізмів участі й взаємодії суб'єктів світової політики, у становленні міжнародного правопорядку в певних галузях, що насамперед визначає «галузеву» спрямованість досліджень, зокрема дослідження проблем «міжнародного морського правопорядку» [7, с. 36, 37]. Отже, на сучасному етапі становлення
України «особливого значення» набуває фактор утвердження ії як морської держави, виходячи з «місця та ролі в глобальній і регіональній системі міжнародних відносин» (Мордок 2018 «Сучасний стан сфери морської діяльності»). Водночас «вплив права» на суспільне життя $\epsilon$ більш значущим, чим «сильніше правові форми здійснюють стимулюючий або «зобов'язуючиий» вплив саме на волю та свідомість людей». Отже, безпосереднім предметом правового регулювання виступає вольова поведінка учасників суспільних відносин, «поведінка, через яку лише й можна здійснювати стимулювання або примус», до того ж, власне характеристика правових режимів «нерідко» ведеться щодо певних об'єктів, але «режим об'єкта» - лише скорочене словесне позначення порядку регулювання, що виражене в характері й об'ємі прав стосовно об'єкта» $[8$, с. 147,171$]$.

Вищенаведене стосується «підтримки свободи відкритого моря» (Мордок 2018 «Національні інтереси на морі»). Звідси природньо виникає необхідність проаналізувати положення щодо визначення та змісту понять «відкрите море», «свобода відкритого моря» та інших понять, які до них стосуються.

Міжнародно-правове

визначення поняття «відкрите море» було закріплено в 1958 році в Статті 1 Конвенції про відкрите море (далі - КВМ) - це усі частини моря, які «не належать ні до територіального моря, ні до внутрішніх вод будь-якої держави» [9]. Водночас як частина морських просторів, що знаходиться «в загальному користуванні всіх держав і народів», вона являє собою «явище суто специфічне» й не може бути охоплена навить правовими концепціями "res nullius" або "res communis" [10, c. 21].

Принцип свободи відкритого моря «лежить в основі й складає суть правового режиму» морських просторів, які мають назву «відкрите море». Історично цей принцип прийшов «на заміну середньовічним притязанням на владарювання над морями». Між юристів-міжнародників «немає одностайності» у питанні коли цей принцип став загальновизнаним принципом міжнародного права. Але, «найбільш правильною представляється точка зору», 
відповідно до якої цей принцип «став безспірним» у практиці держав і теорії тільки із першої чверті XIX сторіччя. Водночас В. Верещєтін стверджує, що «немає та не може бути суто юридичного обгрунтування принципу свободи відкритого моря». Цей принцип «породжений» економічними потребами розвитку суспільства, «він ґрунтується» на визнанні усіма державами світу положення про те, що відкрите море $\epsilon$ необхідним для того, «щоб забезпечити свободу сполучень, торгівлі та судноплавства між усіма народами земної кулі» [10, с. 14,16 , 20]. Міжнародно-правовий зміст поняття «свобода відкритого моря» було розкрито, зокрема, у Статті 2 КВМ [11].

В умовах «суттєвого зменшення» кількості суден під українськім прапором, слід враховувати світовий досвід, який свідчить, що «введення міжнародної реєстрації суден із спеціальним режимом оподаткування» сприяло «концентрації флоту» під національним прапором (Мордок 2018 «Сучасний стан сфери морської діяльності»). 3 вказаного випливає необхідність дослідження загальних питань, пов'язаних із наданням суднам права плавати під державним прапором, наданням їм національності та їх реєстрації.

У 1720 році на підставі перекладів англійського, голландського, датського, французького й шведського уставів було видано «повний морський статут» під назвою «Книга статут морський про все, що стосується доброго управління під час перебування флоту в морі» [12]. у 1781 році було видано «Статут купецького водоходства», але лише в 1865 році в ньому (уперше у Російській імперії) набули свого законодавчого закріплення «реєстрація суден» і надання судновласнику права підняти російський купецькій прапор на власному судні: «1. Право підняття Російського купецького прапору належить виключно російським підданим. $<\ldots>2$. Плавання під Російським прапором дозволяється лише після внесення судна до корабельного списку одного з російських портів і після видачі суднохозяїну належного в тому свідоцтва, що має назву патента на плавання під Російським прапором» [13] (докладніше із цього приводу див.: Курс торгового права Г.Ф. Шершеневіча [14, с. 726-728]).
На засіданні Інституту міжнародного права (далі - ІМП) в 1891 році (м. Гамбург) пан Асcер ("Mr. Asser") порушив питання щодо розроблення уніфікованих для кожної держави правил регулювання умов надання торговельним суднам права плавати під національним прапором. У 1896 році (м. Венеція, 30 вересня) проєкт таких правил було обговорено та затверджено відповідною резолюцією, згідно з якими: «судно має бути включено до реєстру, який ведеться для цих цілей уповноваженими особами, відповідно до законодавства держави» (ст. 1); «до реєстру може бути включення судно, якщо більш ніж його половина $є$ власністю: або громадян; або корпорацій або командитних товариств, у яких понад половини відповідальних за управління осіб $€$ громадянами; або акціонерних товариств, у яких якнайменше дві третини директорів складають громадяни; подібні правила застосовуються до асоціацій або інших юридичних осіб, які володіють судном» (ст. 2); «підприємство (будь-то фізична особа-судновласник, компанія або корпорація) повинна мати свій офіс у державі прапора, і в який воно має бути зареєстроване» (стаття 3); «кожна держава визначає обов'язкові до виконання умови щодо призначення капітана або першого офіцера: водночас громадянство капітана або членів екіпажу не може бути підставою для відмови або позбавлення права на державний прапор» (стаття 4) [15]. Але вже в 1903 році в поясненнях до «Проєкту статей про право плавання під російським прапором» було вказано: «Національність судна залежить не від зовнішніх формальних ознак, а від ознак внутрішніх, які не завжди $\epsilon$ помітними для стороннього спостерігача, а саме: від національності осіб, які вклали свої капітали в підприємство мореплавне, але набагато найслабшою мірою, і від національності осіб, яким довірено управління справами підприємства» [16].

Звернемо увагу на те, що вже в 1927 році ІМП вказував, що свобода судноплавства у відкритому морі здійснюється «за умови виключного контролю держави, під прапором якого плаває судно» [17, с. 339]. В. Верещєтін стверджує, що «виключність (не враховуючи суто визначених випадків) влади над судном» зі сторони держави 
прапора у відкритому морі $\epsilon$ «найважливішим наслідком національності судна». Водночас під «національністю» судна у міжнародному праві розуміють «стійкий правовий зв'язок» між судном і державою, прапор якої воно «носить», «правову приналежність» судна до певної держави [10, с. 29].

Відсутність міжнародно-правового закріплення вимог, навить мінімальних стандартів (критеріїв), пов'язаних із реалізацією державами права надання національності й права плавання під прапором, призвело до появи так званих «дешевих» прапорів, використання яких забезпечувало отримання економічної вигоди, зокрема максимальні прибутки [18], «жодним чином не зважаючи водночас на національний престиж та національні інтереси» $[10$, с. 33]. Згадаємо, що одним з напрямів «просування» національних інтересів $\epsilon$ «піднесення іміджу України як морської держави, зокрема шляхом демонстрації державного прапора» (Мордок 2018 «Розвиток військово-морської діяльності»).

У грудні 1948 році було засновано ліберійський «дешевий реєстр», появу якого пов'язують з Е. Стеттініусом (на цей час бувшим державним секретарем США). Вже в березні 1949 року американський танкер "World peace" уперше вийшов у море під прапором Ліберії, а 1978 рік став «піком» - під прапором Ліберії плавали судна, загальний тоннаж яких склав 81 млн. реєстр. т. Цей феномен пов'язують із тим, що Ліберія надавала свій прапор «на найбільш пільгових умовах». Але пізніше з'являються держави, які «прагнуть продати свій прапор на ще більш пільгових умовах», внаслідок чого до кінця 1988 року «флот Ліберії» скоротився до 49,5 млн. рег. т, але залишався водночас на першому місці у світі [19]. Останнє призвело до того, що Ліберія почала «шукати нові пільги для судновласників щоб утримати їх», а також надавати «серйозні політичні поступки» [20].

Отже, питання щодо надання права на прапор, у першу чергу, «є по суті питання про допуск іноземного капітала до свого торговельного флоту», звідси - у різні часи й у різних країнах ці умови «різко відрізняються один від одного й у кожен момент пояснюються зацікавленістю дер- жав у залученні іноземного капіталу й іншими мотивами» [10, с. 34]. Згадаємо, що для «загального поліпшення стану» морської діяльності необхідно «створити економічні стимули» для реєстрації суден під українським прапором (Мордок 2018 «Мета, принципи і напрями реалізації морської політики»), зокрема «обґрунтованого» податкового режиму судноплавства, що відповідає податковим умовам «відкритих реєстрів європейських держав», i «надання режиму найбільшого сприяння інвестуванню» у морський і внутрішній водний транспорт.

Комісія міжнародного права (далі-КМП), починаючи роботу над питанням національності судна, виходила з того, що в законодавстві більшості держав із цього питання існує «певна одноманітність принципів», тому спеціальному доповідачу з морського права Ж.П.А. Франсуа було доручено з'ясувати загальні принципи, відповідно до яких зазначене питання врегульоване в державах світу. На 3 сесії КМП у 1951 році Ж.П.А. Франсуа виклав правила, що стосуються національності суден «в якості принципів, які прийняті майже всіма державами, що створюють основу міжнародного права в цій сфері:

1. Судно більш ніж на половину має належати:

а) громадянам або особам, які $\epsilon$ доміційованими на території держави, якій належить флаг;

б) повному або командитному товариству, в якому понад половини членів, що несуть особисту відповідальність, $є$ громадянами або особами, які постійно проживають ("des person esétablis») на території держави прапора;

в) національному акціонерному товариству, правління якого знаходиться на території держави прапора.

2. Капітан має бути громадянином держави прапора» [21, р. 77]. Але вже в 1956 році КМП відмовилась від застосування вищенаведених положень і в статті 29 «Остаточного проєкту статей, які відносяться до морського права» (далі - Доклад 1956) було зазначено: «задля визнання національної належності судна іншими державами має існувати реальний зв'язок між цією державою і цим судном». У Коментарях до вказаної 
статті КМП закріплює право кожної держави встановлювати умови надання своєї національності, але водночас такі держави мають визнавати певні обмеження «внутренние законы по этому предмету не должны слишком далеко отступать от тех принципов, которые приняты большинством государств». Тільки за цієї умови визнана за державами свобода не призведе до зловживань та непорозумінь між ними. Щодо положень Проєкту ІМП 1896 року КМП прийшла до висновку про те, що «сформульовані нею критерії не можуть слугувати тій меті, яку вона собі поставила». Виходячи з цього КМП вирішила, що «найкраще за все обмежиться викладенням того керівного принципу, що для загального визнання дарованої національності необхідний «справжній зв'язок» між державою прапора й судном прапора - КМП «вважала за краще вказати незрозумілий критерій, ніж не вказувати жодного». Звідси КМП вважає за потрібне пояснити, що надання націо- нальності «не $\epsilon$ простою адміністративною формальністю, що не супроводжується жодними гарантіями того, що це судно дійсно пов'язане зі своєю новою державою», тобто «фактично існує зв'язок, який має вираження не в одній лише видачі свідоцтва про реєстрацію»

Восьма сесія КМП, заснована на виконання Резолюції 174 (II) ГА ООН від 21 листопада 1947 року відбувалася в Європейському відділенні ООН у Женеві. Доповідь 1956 року належит до роботи, виконаної КМП на цій сесії. У розділі II доповіді міститься остаточна доповідь з морського права, складена КМП згідно з Резолюцією 899 (IX) ГА ООН [22]. Відомо, що положення про «реальний зв'язок» було включено до статті 29 Доповіді 1956 року після розгляду відзивів до її попереднього (1955 року) змісту, зокрема пропозиції, яку було викладено у відгуку Уряду Нідерландів, в якому було висловлено також сумнів у «можливості та доцільності детальних правил» із цього приводу [23, р. 13, 15].

\section{ЛITEPATУРA:}

1. Про внесення змін до Морської доктрини України на період до 2035 року : Постанова Кабінету Міністрів України від 18 грудня 2018 р. № 1108 / Кабінет Міністрів України. URL: https://zakon.rada.gov.ua/laws/show/1108-2018-\%D0\%BF/ed20181218\#Text.

2. Про рішення Ради національної безпеки і оборони України від 12 жовтня 2018 року «Про невідкладні заходи щодо захисту національних інтересів на Півдні та Сході України, у Чорному та Азовському морях і Керченській протоці» : Указ Президента України від 12 жовтня 2018 р. № 320/2018 / Президент України. URL: https://www.president.gov.ua/ documents/3202018-25174.

3. Про невідкладні заходи щодо захисту національних інтересів на Півдні та Сході України, у Чорному та Азовському морях і Керченській протоці : Рішення Ради національної безпеки і оборони України від 12 жовтня 2018 р. / Рада національної безпеки і оборони України. URL: https://zakon.rada.gov.ua/laws/show/n0011525-18\#Text.

4. Философский энциклопедический словарь / редкол. : С.С. Аверинцев, Э.А. Араб-Оглы, Л.Ф. Ильичев и др. Москва : Сов. энциклопедия, 1989. 815 с.

5. Оборотов Ю.М. Сучасна держава: від образу до поняття. Креативність загальнотеоретичної юриспруденції : монографія / за ред. Ю.М. Оборотова. Одеса : Фенікс, 2015. С. 360-369.

6. Джураєва О.О. Динаміка сучасної держави. Методологія та інноватика загальнотеоретичної юриспруденції : монографія / за ред. Ю.М. Оборотова. Одеса : Фенікс, 2019. С. 347-362.

7. Рябошапченко А.О. Сучасні тенденції розвитку міжнародного правопорядку. Юридична наука: виклики і сьогодення : матеріали Міжнар. наук.-практ. конф., м. Одеса, 12-13 червня 2020 р. Одеса : Причорноморська фундація права, 2020. С. 35-37.

8. Алексеев С.С. Теория права. Москва : Издательство БЕК, 1994. 224 с.

9. Конвенція про відкрите море : Міжнародний документ від 29 квітня 1958 р. База даних «Законодавство України». URL: https://zakon.rada.gov.ua/laws/show/995_180\#Text.

10. Верещетин В.С. Свобода судоходства в открытом море. Москва : Издательство ИМО, 1958. 144 c.

11. Конвенція про відкрите море : Міжнародний документ від 29 квітня 1958 р. База даних «Законодавство України». URL: https://zakon.rada.gov.ua/laws/show/995_180\#Text. 
12. Веселаго Ф.Ф. Краткая история русского флота. Москва - Ленинград : Военно-морское издательство НКВМФ СССР, 1939. Глава IV. Состояние морского дела в первой четверти XVIII века. URL: https://flot.com/publications/books/shelf/brief/brief_history_5.htm.

13. Полное собрание законов Российской империи. Собрание второе. 1865. От № 41642-42509. Санкт-Петербург : Типография Второго отделения Собственной его императорского величества канцелярии, 1867. T. XL. Отд. I. 993 c. URL: https://biblioclub.ru/ index. php?page=book\&id=117822.

14. Курс торгового права профессора Казанского университета Г.Ф. Шершеневича. Казань : Типография Импреаторского Университета, 1892. 823 с.

15. USE OF THE NATIONAL FLAG FOR MERCHANT SHIPS (1896-Ven-03). At the meeting at Venice in 1896, Mr. Asser and Lord Reay presented their report together with a draft of resolutions. The discussion in plenary session took place September 30,1896, and resulted in the adoption on that date of the following draft rules: Section I. - Acquisition of the Right to the Flag of a State. Article 1. The ship should be inscribed on the register kept for this purpose by authorized officials, in conformity with the laws of the State. Article 2. To be inscribed on this register, more than half the ship must be the property: 1 . Of nationals; or 2 . Of a company under a collective name or a commandite, of which more than half the members personally responsible are nationals; or 3. Of a national stock company (joint-stock or commandite), two-thirds at least of the directors of which are nationals; the same rule applies to associations and other legal persons owning ships. Article 3. The concern (whether an individual ship-owner, a company or corporation) must have its head-quarters in the State whose flag the ship must fly and in which it must be registered. Article 4. Each State shall determine the conditions to be fulfilled in order to be appointed captain or first officer of a merchant ship: but the nationality of the captain or that of the members of the crew shall not be a condition of acquiring or forfeiting the right to the national flag / English resolutions. Part I. Unofficial translations of public law resolutions (1875-1913) by J.B. Scott. URL: https://www.idi-iil.org/app/uploads/2019/06/Annexe-1bis-Compilation-Resolutions-EN.pdf.

16. Проект статей о праве плавания под русским флагом с объяснениями. Главное управление торгового мореплавания и портов. Санкт-Петербург, 1903. С. 3 (цит. за: Верещетин В.С. Свобода судоходства в открытом море. Москва : Издательство ИМО, 1958. С. 30).

17. V. La navigation en HAUTE mer (VII Commission). I. L'Institut de Droit International déclare quele principe de la liberté de la mer, comporte notamment les conséquences qui suivents 1. Liberté de navigation en haute mer, sous le contrôle exclusif, saufconvention contraire, de I'Etat dont le navire porte le pavillon; <...> / SESSION DE LAUSANNE. AOUT-SEPTEMBRE 1927. Annuaire de L'Institut de Droit International. T. 33. Part. III. 1927. URL: https://www.idi-iil.org/ app/uploads/2017/05/4025-33C_OCR.pdf.

18. Коротаев А.В. Некоторые проблемы судоходства. Морской флот. 1956. № 12. С. 29-30.

19. Булушев Ю.А. Блуждающие флаги. Морской флот. 1956. № 12. С. 25-26.

20. Яшин С.О. Пионер «удобного» флага. Морской флот. 1989. № 9. С. 48.

21. La Commission du droit international pourrait examiner la possibilité de proclamer comme principes adoptés par la presque totalité des États et formantla base du droit international à cet égard, les règlessuivantes: 1. Le navire doit être pour plus de la moitié la propriété: a) De nationaux, ou de personnes établies sur leterritoire de l'État du pavillon; b) D'une société en nom collectif ou en commandite simple, dont plus de la moitié des associés personnellement responsables sont des nationaux ou des person esétablis sur le territoire de l'État du pavilIon; c) D'une société par actions nationale qui a sonsiège sur le territoire de l'État du pavillon; 2. Le capitaine doit avoir la nationalité de l'État du pavillon: Document: A/CN.4/42. Second Report on the Regime of the High Seas by Mr. J.P.A. François. Special Topic: Law of the sea régime of the high seas. Extract from the Yearbook of the International Law Commission. 1951. Vol. II. URL: https://legal.un.org/ilc/documentation/english/a_cn4_42.pdf.

22. Организация Объединенных Наций. Доклад Комиссии международного права о работе ее 8 сессии (23 апреля - 4 июля 1956 года). ГА. Официальные отчеты. Одиннадцатая сессия. Дополнение № 9 (А/3159). Нью-Йорк, 1956. С. 8-10, 13.

23. Article 5: Right to a flag. 50. The Netherlands Government proposes that article 5 be replaced by two other articles worded as follows: "Article 5a". Each State may fix the conditions 
for the registration of ships in its territory and the right to fly its flag. Nevertheless, for purposes of recognition of the national character of the ship by other States, there must exist a genuine connection between the State and the ship. "Article $5 b$ ". States shall issue for their ships regulations in order to ensure the safety at sea inter alia with regard to: "1. The adequacy of the crew and reasonable labour conditions; "2. The construction, equipment and seaworthiness of the ship; "3. The use of signals, the maintenance of communications and the prevention of collisions". In issuing such regulations the States shall observe the standards internationally accepted for the vessels forming the greater part of the tonnage of sea-going ships. "States shall take the necessary measures in order to guarantee the observance of the said regulations. To that effect they shall provide inter alia for the registration of the ship in the territory of the State and for the documents showing that the pertinent regulations of national legislation have been observed". 51. The Netherlands Government also wishes to combine the matters governed by articles 5 and 9. It doubts whether it is possible to lay down detailed regulations concerning the right of States to grant permission to fly their flag. It considers that the article should merely state the principle that there must be a genuine connection between the ship and the State / Regime of the high seas and of the territorial sea (Doc. A/CN.4/99/Add. I) / DOCUMENT A/CN.4/97/Add. I to 3. Summary of replies from Governments and conclusions of the Special Rapporteur. Yearbook of the International Law Commission, 1956. Vol. II. Documents of the eighth session including the report of the Commission to the General Assembly. UNITED NATIONS, New York, 1957. URL: https://legal.un.org/ilc/publications/yearbooks/english/ilc_1956_v2.pdf. 